\title{
On the typology and the worship status of sacred trees with a special reference to the Middle East Amots Dafni*
}

\author{
Address: Institute of Evolution, Haifa University, Haifa 31905, Israel \\ Email: Amots Dafni* - adafni@research.haifa.ac.il \\ * Corresponding author
}

Published: 15 May 2006

Journal of Ethnobiology and Ethnomedicine 2006, 2:26 doi:10.1186/1746-4269-2-26

This article is available from: http://www.ethnobiomed.com/content/2/1/26

(C) 2006 Dafni; licensee BioMed Central Ltd.

This is an Open Access article distributed under the terms of the Creative Commons Attribution License (http://creativecommons.org/licenses/by/2.0), which permits unrestricted use, distribution, and reproduction in any medium, provided the original work is properly cited.
Received: 12 February 2006

Accepted: 15 May 2006

\begin{abstract}
This article contains the reasons for the establishment of sacred trees in Israel based on a field study. It includes 97 interviews with Muslim and Druze informants. While Muslims (Arabs and Bedouins) consider sacred trees especially as an abode of righteous figures' (Wellis') souls or as having a connection to their graves, the Druze relate sacred trees especially to the events or deeds in the lives of prophets and religious leaders. A literary review shows the existence of 24 known reasons for the establishment of sacred trees worldwide, II of which are known in Israel one of these is reported here for the first time. We found different trends in monotheistic and polytheistic religions concerning their current worship of sacred trees.
\end{abstract}

\section{Background}

Frese and Gray [[1]: 26] write: "Trees are a form of nature that represent life and the sacred continuity of the spiritual, cosmic, and physical worlds. A tree is often used to symbolize a deity or other sacred beings, or it may stand for what is sacred in general... Trees represent certain deities or ancestors, serve as mediators or as a link to the religious realm, and are associated with cultural beliefs in heaven or the afterlife... Through association with particular religious or historical events, an individual tree or species of tree acquires the symbolic significance of the events as part of its meaning. A society's religious beliefs about the kinds of trees that are sacred generally depend on the nature and number of trees found in the territory. If trees are plentiful, the forest as a whole will also be an important part of the religion's spiritual beliefs and rituals".

Hughes and Chandran [[2]:78] have already noticed that sacred groves developed originally in traditional societies, which considered themselves linked in a web of spiritual relationships with their biophysical environments. Trees have always been regarded as the first temple of the gods, and sacred groves as their first place of worship; they were held in the utmost reverence [[3]:12.2.; [4]:471; [5]:203; [6]:190; [7]:45; [8], I: 87]. Sacred individual trees and groups of trees characterized almost every culture and religion where trees were capable of growing [[9]:4; [4]:467; [10], I: 109-135, [11]:414; [12]:57; [13]:30]. Thus, it is not surprising to find traces of tree worship in the Middle East [[14]:187]. There is even evidence about the magnitude of tree worship in Palestine in the $19^{\text {th }}$ century "yet in no country are the people more awed by trees than in Palestine" [[15]:54].

It is recognized that trees are not worshipped for themselves but for what is revealed through them, what is implied and signified [[16]:268; [17]:28], especially some kind of power that they express [[18]:35; [19]:359; [12]:57] or their being the abode of supreme beings 
[[20]:91]. Eliade [[21]:149] noted, "The image of the tree was not chosen only to symbolize the cosmos but also to express life, youth, immortality, wisdom. In other words, the tree came to express everything that religious man regarded as pre-eminently real and sacred" (italics in the original). It seems that worship of trees began, among other reasons, because of their long life. In most ancient civilizations trees, whose life-span is several times greater that man's, were treated with the same respect as the elders among men Several generations lived in the shade of the same venerable tree, almost as if it were eternal [[22]:276].

Strangely enough, despite the long list of specific books devoted solely to tree worship [[23]:9; [24]:25; [20]:26; [27]:28; [29]:6], we were unable to find any definition of a "sacred tree". Several authors recognize some "categories" of sacred trees (e.g., [[30]:448; [27]:5-20; 12:5867]), some of which are not mutually exclusive. To clarify the "hallowed" status of trees, in Israel, we must elucidate the conceptual difference between "blessed", "sacred", and "holy" trees. The difference is not merely semantic but reflects the religious attitude to the adoration of trees. According to the Druze religion only people like prophets could be "sacred"; physical objects like trees may be regarded only as "blessed" [31]. A plant species all of whose specimens are worshipped owing to religious tradition (regardless the exact background) has to be treated as "holy". Simoons [1998:293] distinguishes tree rituals wherein a certain species of tree is considered "holy", as in the case of the sacred fig (Bo tree, Ficus religiosa L.), from rituals in which individual trees are "sacred" because of special characteristics or have won respect through their location in a holy place or their association with a holy person (see also [[33]:150] for a similar distinction).

The literature survey shows that the definitions of "sacred tree/wood/grove/forest" are by no means mutually exclusive due to the complexity of reasons for, and the history of, the sanctification of the individual tree, a tree species, or a group of trees. Several authors supply definitions of sacred forest/grove/wood: for example, "... a sacred grove is a stand of trees in a religious context" [[34]:1]; " Sacred trees... describe individual trees or woods which were treated with a certain reverence which, normally, protected them from a wilful damage "[[35]:16]; "Clusters of forest vegetation that honour a deity, provide sanctuary for spirits, remind present generations of ancestors or protect a sanctified place from exploitation. They are treated as sacred by virtue of their location, cultural meaning and history", [[36]:30]; "Sacred grove is a patch of forest or natural vegetation protected and managed by the community considering it to be the reside place of the deities or ancestral spirits" [[37]:2]; for similar definitions see also [[38]:225; [40]:49]; "Sacred groves are more or less patches of climax vegetation... preserved on a religious ground" ([[41]:272] see also [[42]:1063; [43]:1204; [44]:1541-1542]). Freeman [[45]:262]) criticized these "ecological" definitions because they were derived from a botanical ideal (climax) and not based on local understanding; his definition is "a piece of garden or forest land... that is dedicated for the exclusive use of particular deities".

Hughes and Chandran [[2]:69] supply a comprehensive definition for a sacred grove as follows: "Segments of landscape containing trees and other forms of life and geographical features that are delimited and protected by human activities believing that preserving such a patch of vegetation in relatively undisturbed state is necessary for expressing one's relation to the divine or to nature".

Gupta [[20]:19] distinguishes a "tree-god", whose worship became organized into a definite religion, from a "tree spirit", whose propitiation degraded the level of sorcery and incarnation. In practice it is impossible to discern, "spirits", "demons", and "jinns" (general supernatural agents) as against "goddesses, "gods", and "the deity" (religiously established worshipped elements). In the Middle East and North Africa, specific trees may be considered the abode of jinns, demons, or spirits, but these supernatural powers are never worshipped as a kind of "god". No religious ceremonies are associated with or performed near these trees; these are regarded as heathen rites and are strictly prohibited.

The various definitions of "sacred tree/grove/wood/forest" may be classified according to four groups of criteria: A. natural elements: the physical characters of the tree; $\mathbf{B}$. supernatural elements believed to reside in the tree and act upon humans. C. human ritual behaviours related to the trees and $\mathbf{D}$. botanical criteria such as climax and high biodiversity. A sacred tree/grove/wood/forest may contain the following seven elements: 1 . It is the abode of a supernatural power. 2. It is well delineated physically/geographically. 3. The trees are protected by taboos from cutting/exploitation/disrespect/secular behaviours. 4. It is related to historical/cultural/religious issues. 5 . The area is protected to please the supernatural powers so as to ensure their benevolence or to avert their malevolent power. 6. It is a piece of natural vegetation (in most cases). 7. It is a ubiquitous phenomenon not limited to any specific religion or geographic territory.

As a practical working definition we suggest treating "sacred trees" as "trees that are subjected to practical manifestations of worship, adoration, and/or veneration that are not practised with ordinary trees". These trees could be single units, groves, forests, or all the specimens of a certain botanical species. 
Many religions relate to "metaphysical" trees such as "cosmic tree", "sky tree", "inverted tree", "tree of life", "celestial trees", " tree of wisdom", and "tree of knowledge". These "types" are not mutually exclusive [[6]:273-278; [1]:27-28, [[9]:1-23] Some of these "spiritual trees" are identified with specific species: The Indo-European cosmic and tree of life with oak [[6]:278], the Indian "sky tree" with Ficus religiosa [[1]:27], the Assyrian tree of life with date palm [[46]:8-13; [47]:132-133]; while the Egyptian "tree of life" is identified as a date or as sycamore (Ficus sycamorus) [[48]:76]. Belief in "metaphysical trees" is not necessarily evidence of practical tree worship [[6]:272].

In this study we exclude "metaphysical trees", while taking into consideration that sometimes the boundary between these trees and reality is not clearly delineated. The present paper is an attempt to elucidate which causes of tree sanctification are characteristic of the Middle East as against other regions, and if differences exist among ethnic groups in Israel on this matter.

\section{Methodology}

The field study (1999-2005) centred on Arab, Bedouin and Druze villages in Galilee. Informants were asked about the reasons why certain trees became sacred. The survey covered 97 informants, consisting of 38 Druze, 59 Muslims (36 Arabs and 23 Bedouins). We consider "Arabs" people who have been settled in their villages for several centuries, "Bedouins" people who originated from the deserts of Israel and Jordan, migrated to the Galilee at the last three centuries and were nomadic till the end of the $20^{\text {th }}$ century [[49]:30]. The Druze are an East Mediterranean group adhering to a religion that was established in Egypt the $11^{\text {th }}$ century [[50]:3]. Today they are concentrated in Lebanon Syria and Israel [[50]:8-14]. The belief in the revelation of God in the form of a human being is considered the most important fundamental principle of the Druze faith [[50]:15]. Druze faith is not ritual-ceremonial religion in essence, but rather a neo-platonic philosophy [[9]:17].

We distinguish "Arabs" and "Bedouins" in attempt to discern different traditions regarded sacred trees which may reflect the different origin of nomads and settled village people. The survey excluded Christians, who hardly believe in sacred trees, while in the Jewish sector the adoration of trees is a new trend of the last two decades and almost all the worshiped trees are already known as old Muslim sacred ones in the vicinity of graves of supposed historical Jewish righteous personalities.

In each village we made a preliminary survey to locate the knowledgeable people in advance and we also approached important religious leaders to examine theirs attitudes to the veneration of sacred trees, then informants were chosen according to their knowledge of common traditions and/or religious status. The average age of the informants was $57.7(+/-14.8)$ years. Respondents were 95 males and two females (in general women are reluctant to be interviewed, and when they agreed the interview was held in the presence of other family members). Because of the refusal of most of the informants to be videotaped or recorded all the study is based on oral interviews and field notes that were taken on the spot. The interviewees were asked, "Why have specific trees [especially in their home village] become sacred?" and "How is al-Khader [= Elijah] related to trees?" this question was introduced because this prophet is the most popular one (see below) and at not less that 30 sacred trees are named in his honour [50, Dafni, unpubl.].

\section{Results}

The answers for the question "Why are trees venerated?" are presented in Table 1

When the interviewees were asked "why trees are venerated", they gave the following answers (the bold numbers are related to certain informants, see Appendix):

1."The sacredness of the tree originated only from a sacred tomb or the place of a Welli" (23 infor-mants).

2."A man that prays to a tree is a heathen; we need to pray only to God. The tree is temporal, only God is eternal. If the sacred tree is not able to protect itself against being cutting down, how will it protect humans? We have to pray to God, who is the Creator. We have to worship God, not trees" (1).

3. "We have to believe in God, not in trees; it is against the religious law" (2).

4. "God protects sacred trees" (3).

5. "Sanctity rests only on prophets; it is forbidden to sanctify objects like stones and trees" (4).

6." People have prayed to trees since Roman times, and [the tendency] remains inside the human. I believe only in one God" (5).

7." The sacred tree is a path between man and god" (6).

8. "The importance of the sacred trees depends on the saint; the holier the man, the holier is the tree " (7).

9. "Sacred trees are the memento of a saint or holy man, so their importance is relative to the man's holiness" (8). 
Table I: Reasons for sanctification of trees Numbers indicate the percentage of informants in each ethnic group that gave a certain reason.

\begin{tabular}{|c|c|c|c|c|c|}
\hline Reason & Druze & Arab & $\begin{array}{c}\text { Bedou } \\
\text { in }\end{array}$ & $\begin{array}{l}\text { References } \\
\text { from Palestine }\end{array}$ & Other regions (selected references). \\
\hline $\begin{array}{l}\text { I. Tree is the abode of a Welli's/saint's } \\
\text { spirit. }\end{array}$ & 0 & 58.3 & 52.0 & $\begin{array}{l}{[60: 303,331 ; 55: 9} \\
\text { I; } 57: 264 ; \\
56: 152 ; 106: 89]\end{array}$ & [Iraq (107:92); Iran (87,I:375;108:3I7); Turkey (65:4I)] \\
\hline $\begin{array}{l}\text { 2. A saint is buried near/under the } \\
\text { tree. }\end{array}$ & 2.6 & 52.7 & 21.7 & $\begin{array}{l}{[55: 93,61: 27} \\
62: 242]\end{array}$ & $\begin{array}{l}\text { [Morocco (59:67; Turkey (58:227); Algeria (109:3 II); } \\
\text { Turkey (I 1 0:2 I5)] }\end{array}$ \\
\hline $\begin{array}{l}\text { 3. Religious and social meetings take } \\
\text { place under the tree; well-known } \\
\text { figures are associated with the tree. }\end{array}$ & 71.0 & 44.4 & 30.4 & {$[56: 71 ; 111: 36]$} & $\begin{array}{l}\text { [Ancient Assyria (I I 2:42); Iran (92: 142); Morocco (59:68); } \\
\text { India (73:19-28)] }\end{array}$ \\
\hline 4. The tree is dedicated to a prophet. & 47.3 & 22.2 & 34.7 & {$[56: 65]$} & \\
\hline 5. The species is religiously blessed. & 26.3 & 19.4 & 17.3 & {$[31]$} & \\
\hline $\begin{array}{l}\text { 6. The tree/forest commemorates } \\
\text { events in the lives of saints, heroes, } \\
\text { kings, in the tribe's history etc.. }\end{array}$ & 36.8 & 41.6 & 26.0 & $\begin{array}{l}{[106: 51 ; 55: 93} \\
113: 95]\end{array}$ & 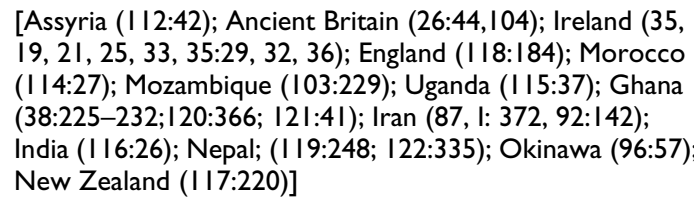 \\
\hline 7. The tree shows the way to a sacred & 92.0 & 0 & 0 & & \\
\hline
\end{tabular}

7. The tree shows the way to a sacred place.

8. The tree sprouted from saints' staffs.

9. Tree provides shade in the desert 10. The Tree Grows/is planted over the grave of the saint.

II. The tree is sacred because of the tree's size, age, shape; being evergreen or having a strange form.

12. The tree has healing powers.

13. The tree is the abode of supernatural beings: tree spirits, djinns, demons, deities, goddess, angels, divine beings, dragon, monsters, etc.,

14. All the individual trees of the species are religiously sacred.

15. To commemorate miracles occurred near the tree or related to a saint.

16. Tree is abode of ancestors' souls.

17. The tree is located near holy water source.

$\begin{array}{llll}7.8 \quad \text { II. } & 4.3 \quad[56: 27 ; 124: 407 \\ & & & 125: 378-379]\end{array}$

$\begin{array}{ccc}0 & 0 & 17.3 \\ 2.6 & 2.7 & 0 \\ 0 & & \end{array}$

[106:89]

$\begin{array}{lll}0 & 5.5 & 0\end{array}$

$\begin{array}{ccc}0 & 0 & 0 \\ 0 & 2.7 & 0\end{array}$

$0 \quad 0 \quad 0$

$\begin{array}{llll}0 & 0 & 0 & {[(56: 70]}\end{array}$

$0 \quad 0 \quad 0$

$0 \quad 0 \quad 0$
[England (26:2I); Ireland (35:35, 38, 40); Poland (6:55); Morocco (59:68); Iran (I25:4I); India (I 26 (127:287 in 2I:27); New Zealand (128:68)]

[Ancient Egypt (129:12I); Iran (87,I:373); India (130:43)] [Ancient Celts (5:202); Egypt (66:56); Morocco (63:80); Zanzibar (I3I:36); Mongolia (79:2830]

[Ancient Greece (76:26; 34:10); Ancient Rome (3, 12.2.3.; 132:67); Pagan Europe (74:38; 132:67); Russia (133, I:194); Siberia (141:58); Armenia (135:320); East Africa (78:4); Kenya (139:151); Cameroon (140:100); Sierra Leone (136:47); Iran (92: 142); Inner Mongolia $(80: 279,283)$; India (I37:239); China (I38:759); Taiwan (I34:5,III, I)] [Britain (26:44); Uganda (I43, II: 832); China (I42:4I I4I3)]

Ancient Egypt (I5I:89; 70:40); Minoan (I52:14I); Ancient Greece (34:10, 16, 20); Ancient Celts (5:198); Old Scandinavia (6:52); Teutonic mythology (8,I:7I); East Africa (78:4); Uganda (I 15:37); Zimbabwe (101:6); India (98:9, I5; 1 37:240,242); Ethiopia (154:3); Zanzibar (131:35); Mozambique, 103:229); Sierra Leone (156:102); Nigeria (I57:292); West Africa (I58:44); East Africa (78:4); Central Africa (159:3 I7); Siberia (I55:I I7); Iran (144:125); Inner Mongolia (80:277); Nepal ( I50:334); India (137:242; 40:280; 43: 1578; 153:47); Thailand (147:330, 147:66); China (I38:759; |6I: I 3I); Japan (I45:34,35; 60:176); Indonesia (148:3 I7);Okinawa (96:46,57,63; I49:I77);Micronesia (102:9); Papua (162:72)]

[Dahomey (172:54); India (165); Armenia (166:5); Tibet (168:325); China (138:759); Micronesia (167:13); Kiribati Pacific Islands (102:46); Chile (169:146); American Indians $(164: 121)]$

[Ireland (35:37,43); Egypt (90:17); ]Morocco (59:67,259); Iran (108:3 I7); India (137:243); Tibet (I7I:276); Taiwan (134:5,III, I); China (I72:133)]

[Old Celts (5:103); Mozambique (I03:23I); Ghana (I2I:4I); Madagascar (176:19,20, 177:61); Zimbabwe(101:6,9;126, :378); Sierra Leone (136:47); S. Rhodesia, (178:102); Ghana (120:366; 179:149, 18:35); Kenya (180:135; French Guinea (I8I:14); Inner Mongolia (80:277,280); India (I37:242; 173:332; 38:593); Laos (174:4; 182:7); Indonesia (I75:310,3 I8); Papua (162:72); Australia (183:163)] [Ancient Greece (34:20,25,34); Ancient Syria (82:115); Ireland (35:40-42; 83:30); Egypt (90: 17); Algeria (184:72); Tanganyika (185:39); Turkey (I I0:2I5); China (I38:759)] 
Table I: Reasons for sanctification of trees Numbers indicate the percentage of informants in each ethnic group that gave a certain reason. (Continued)

\begin{tabular}{|c|c|c|c|c|c|}
\hline $\begin{array}{l}\text { 18. Tree/grove is grown/planted in } \\
\text { sacred places, burial sites, graveyards, } \\
\text { temple worship sites. }\end{array}$ & 0 & 0 & 0 & & 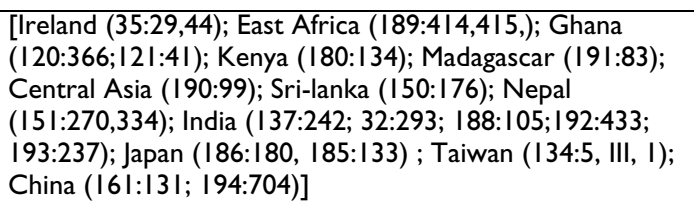 \\
\hline 19. The tree is useful. & 0 & 0 & 0 & Sinai $(195: 184)$ & $\begin{array}{l}\text { [Ancient Assyria (II 2:42); Europe (5:199; 6:149); Ethiopia } \\
\text { (154:4); Nigeria (157:292); S. Rhodesia (178:126-127); India } \\
\text { (137:252, I96:I57, 196:400; 73:21); Himalaya (38:58)] }\end{array}$ \\
\hline $\begin{array}{l}\text { 20. Tree creates a religious } \\
\text { atmosphere }\end{array}$ & 0 & 0 & 0 & & $\begin{array}{l}\text { [Ancient Rome (196:IV, I2, 3: 6:52); India (201:67; 199:153, } \\
\text { 1981:28I)] }\end{array}$ \\
\hline 21. The tree attracts lightning & 0 & 0 & 0 & & $\begin{array}{l}\text { [Europe }(202: 676 ; 203: 79 ; 6: 161) \text {; India (137:239); American } \\
\text { Indians }(204: 15) \text { ] }\end{array}$ \\
\hline 22. God is transformed into a tree. & 0 & 0 & 0 & & [Ancient Egypt (205: 15.16; 14:191); Russia (100:700)] \\
\hline $\begin{array}{l}\text { 23. The grove/forest declared sacred } \\
\text { to insure the community resources/ } \\
\text { water catchments }\end{array}$ & 0 & 0 & 0 & & $\begin{array}{l}\text { [Uganda(I I 5:38);Mozambique (207:12);India ([206:8); China } \\
(163: 131)]\end{array}$ \\
\hline $\begin{array}{l}\text { 24. Planting a tree in high places as an } \\
\text { abode for gods }\end{array}$ & 0 & 0 & 0 & & Mongolia [79:282]. \\
\hline
\end{tabular}

10." The blessed tree is a symbol of the prophet, not an object per se" (9).

11." Holy is that which is sanctified by God, blessed it is by humans'" (10).

12."Each blessed tree has an angel or jinn or demon that resides inside and protects it" (11).

13. "Religious people give the tree their sacredness; maybe the saint planted the tree or was buried underneath it" (12).

14. "Holiness is accorded only to the prophets and it is forbidden to sanctify objects like trees and stones" (13).

15. "Faith gives the strength and a tree near a sacred grave gives blessing" $(14,15)$.

16."In our religion (Druze) we don't sanctify people or trees, only God" (15). "We love the Prophet but we don't sanctify him" (16).

17."Blessed trees are memorials to singular figures in Druze history and religion; because the Druze tradition forbids any tomb sign or offerings, special people are remembered by large blessed trees" (17).

18."The man (a religious figure) is sacred and the tree is blessed. The tree belongs to the people and the saints are the prophets and God". "The blessed trees are a monument to special figures in the history of the Druze religion. In our religion there are no gravestones or offerings in graveyards; the trees commemorate the deeds of these special personalities" (11).
When our informants were asked, "How is al-Khader related to trees?" we received the following answers:

1. "Every tree that is dedicated to al-Khader is a blessing; he is even closer to God than Nabi Shu'ayb (the Druze's most important prophet)" (15).

2. "Al-Khader has the power of 70 prophets" (18).

3. "Every place where al-Khader sat became green" (12 informants).

4. "The place is sacred and green because al-Khader rested there" (11 informants).

5. "The colour of al-Khader is green" (21 informants).

6. "al-Khaher had the habit of sitting under trees", "alKhader is related to trees", or "al-Khader loves trees" (12 informants).

Based on Table 1, the analysis of the interviews, additional field observations and the literature survey we find the following trends: (figures in parentheses are the numbers as in Table 1).

1. The most common reasons for the sanctity of a tree are its being the abode of a saint's (Welli's) spirit and the location in its vicinity being the grave or shrine of a saint ("Makam"); these two reasons were strictly confined to Muslims and were never given by Druze.

2. Dedication to a prophet, the most popular of whom is al-Khader. 
3. Religious and social meetings: The most common reason given was that the tree was a place beneath which religious leaders used to gather for preaching/discussions/ meetings/court sessions/judgements. This reason was more represented among Druze than among Muslims.

4. Events in lives of saints. These may include praying, preaching, resting, living or visiting under the specific tree. This reason seemed similarly represented among the three ethnic groups.

5. The tree species is adored because of a religious dedication: the only tree that in this category was Ziziphus spina christi (see [31] and below).

6. The tree shows the way to a sacred place: this reason was given only by Druze, all of whom

mentioned one specific tree (see below).

7. Some reasons $(13,14,16,18)$ which seem to be connected especially to polytheism are absent from the Middle East.

8. Some reasons that are known from the classical world, as well as from pagan Europe, are very rare or not known today in the Middle East $(10,11,13,14,15,16,17,19,20,21,22)$.

9. All the recorded reasons (except "showing the way to a sacred place") are already mentioned in the literature especially in ancient Europe, North Africa, and the Fertile Crescent.

10. Some reasons, as far as the author is aware, have never been recorded in the Middle East: (12-14, 16-18, 20-24).

\section{New and abandoned sacred trees}

During our study we came upon four cases in which the "sacredness" of a tree could be declared "de novo" or annulled for political as well as religious reasons.

On the Jewish Day of Atonement in 2003 several people from the Druze village of Dalyat al-Karmel (Mt. Carmel) decided to annex an area that was in dispute with Israel's Nature Reserve Authority. In an organized operation an asphalt road was paved and a large oak tree (Quercus calliprinos) in the at Nahal Alon Nature reserve, was declared blessed and a new religious building ("Khalva") was erected at this place. By this act the authorities were forced to accept the Druze claim to the area $(19,20)$. After the religious ceremony the local people accepted the tree as blessed and since that day they regularly place put rags and flags on it, and honour the tree as is customary with every "sacred tree". The action was "covered" by a reli- gious tradition (21). The local keeper of the "Khalva" related that a note dating back 180 years was found in one of the holy books. It told of a pious virgin, "Sit Khadra", (the green lady) who lived in the area and was famous as a successful farmer. After this note was found it was decided to sanctify the area in which she was lived to commemorate her (22).

A case of withdrawal of sanctification occurred in the town of 'Arrābe (Lower Galilee). There stands a very famous ancient tree of Pistacia atlantica, which is "the" sacred tree of the village. It is named "the tree of the Saddik (righteous man)" believed buried under it. In 1961 an archaeological excavation discovered that this was a Jewish grave (the burial direction was north-south, not westsouth as in the Arab tradition). The authorities constructed an old-style building and named it officially after "Khanina Ben Dossa". A famous Talmudic sage (the tradition concerning this burial place is dated to the $10^{\text {th }}$ century [[52]:324-325; [53]:152-155]. From the time the tomb was declared Jewish, the appeal of the tree as sacred to the Muslims declined and fewer people go there to ask the help of the righteous man buried underneath. The various informants $(\mathrm{n}=10)$ held conflicting views as to whether the change was influenced by the local religious leaders.

Similarly, recently (around 2002) religious leaders in the village of Mes'hed (near Nazareth) were unhappy about the veneration by Jewish people of a tree in its midst (a large Pistacia atlantica that is a centre for vows and is abundantly visited by local people as a "wishing tree"). Nevertheless, people continue to visit the tree as usual (23). In the town of Sakhnin (Lower Galilee) there is an ancient cave containing the tomb of Rabbi Yehoshua D'Sikhnin [[52]:302-303, [[53]:150-151]. The place is renowned throughout the region for its miraculous powers to cure sick people, and especially barren woman. Very close to the cave there is a large sacred Ziziphus spina christii tree stands in the middle of an Arab cemetery. In 1980 a local Muslim religious leader decided to forbid the attachment of rags to the tree as well as prayer there, because the place was sacred to the Jews but not the Arabs. The ban held for five or six years, after which the Muslim people returned to their old tradition, saying that the Jewish saint helped them (24).

\section{Discussion}

All the known reasons for the establishment of the sacred trees/groves/forests may apparently be sorted into several generalized categories: dedication to supernatural beings/ powers, relation to established religious rituals and ceremonies, dedication to people, commemoration of historical or miraculous events and practical, economic and conservational reasons. It is noteworthy that in a single 
community/religion more than one reason, for the establishment of a sacred grove (and we suggest to extending this to all types of sacred/holy trees) may be established. More than one aspect was caused by a combination of economic, religious, social and environmental factors, to yield of social, environmental, economic as well as religious reasons [[55]:30]. Political as well as religious reasons could lead to the declaration of new "sacred tree" or to the denial of well known existing ones, as was shown in this study.

\section{Trees as an abode of a saint's spirit}

As it can be seen (Table 1) the most common "function" of the sacred trees in the Middle East is to serve as the abode of the spirit/soul of a saint (Welli). Curtiss [[56]:75, $77,79]$, regarding the status of saints in the Muslim world, noted "... orthodox Moslems insist that the saints are only mediators that a worshipper asks his Welli to intercede for him with God... These saints are really departed spirits, connected with some particular shrine, chosen because they revealed themselves there in the past, and where they are wont to reveal themselves now to these who seek their favour .... The worship of the saints is like that of the ancient Baalim. They are the deities whom people fear, love, serve and adore". Cannan [[57]:151] held that "The present-day peasant does not venerate the trees themselves but the divine-power which acts in them and which is derived from the godly person whose soul is supposed to be still inhabiting the shrine, tomb, cave or spring with which they have become associated. Often these holy men have appeared either in the tree itself or near by". The objection of the religious leaders, and role of the tree as mediator, were also stressed by our informants.

\section{Trees and saints' graves}

In the Middle East, as in North Africa, a saint's grave is closely connected to a sacred tree; trees beneath which saints are buried are regarded as "sacred trees" [[56]:93]. The identification of the sacred tree with the saint's grave imparts to it the miraculous and magical powers of the holy man [[58]:264; [56]:94; [57]:71; [59]:176-177]. Westermarck [[60]:74] comments that the existence of sacred groves around saints' tombs maybe related to the people's avoidance of cutting down these trees for fear of the saint's retribution, even in places where there is no tomb but only a tradition of the holiness of the location, especially in cases where it is not at all clear who the saint is. Thus it seems (in Morocco) that the worship site exists owing to the grove more that the grove exists owing to the site. Canaan comments that sacred trees that are not connected with graves never bear the name of a specific personality [[6]:70]. Our data show that this is not a rule, and today many sacred trees in Israel are not related to tombs; however, these structures might have disappeared in the course of time. Because tradition relates the tree to a saint, it is respected accordingly [[61]:331; [62]:27-28]. In practice it is impossible to determine which came first, the tree or the grave, because of the customs of burying important people near sacred trees [[63]:242] and of planting trees on saints' graves (Morocco [[64]:80]. Hasluck [[59]:238] concluded on this subject in Turkey, "It is often impossible to say whether the sacredness of these groves is primitive and their connection with saints evolved from it, or whether it is secondary and due to their proximity to saint's graves"; the same situation exists in Syria [[65]:179] (at that time Palestine was a part of "Great Syria").

Zarcone [[66]:41] notes that certain trees are sacred because of their connection to a specific figure in the Islamic tradition, and tree veneration may be the fusion of tree worship in general as a part of the supernatural. So sometimes the tree confers holiness on a specific site or a sheikh's tomb as a part of his hagiography. Blackman [[67]:57] mentioned that (in Egypt) trees were sanctified because they grew at a place where a saint was murdered and they bear his soul. He also argued that this is parallel to the ancient Egyptian myth that the sycamore (Ficus sycamorus) grew out of the dead body of Osiris [[68]:29,339].

The conclusion is that it is not clear if the tree became sacred because of the saint, or the personality became sacred because of the tree.

\section{Social and religious meetings}

Especially among the Druze, trees acquired their sacredness through the habit of historical religious leaders meeting under them, to preach or/and to discuss religious issues. When leaders from Lebanon used to visit their faithful in the Galilee they customarily met their local colleagues beneath these trees, which came therefore to be considered "blessed". Sacred trees can't be considered as an abode of a soul because the Druze believe in the transmigration of souls, a person's body is a kind of clothing for the soul, and with the person's demise the soul passes over to the body of a newborn child" [[9]:60]. Thus, souls cannot reside in a tree and graves are not revered, trees were blessed on account of the visits of the religious leader; but souls are never connected with trees.

\section{Dedication to a prophet}

In all the ethnic groups we found sacred trees that were dedicated to a prophet. When we asked specifically who the most common, people mentioned al-Khader, who is highly respected by Muslims as well as by Druze. Not less than 30 places (some of which contain "sacred trees") in the Holy Land are named after him [[69]:13-34]. This prophet is adored by Druze as well by Muslims. Al-Khader (also Al-Khidr or Al-Khudr), who has common features that characterize Elijah and St. George [[8]:48-65], is the 
most popular of all saints in the Middle East [[56]:84; [70]:288; [59]:319-336]. This prophet is closely connected with sacred trees, as was also found in this study. This notion is revealed in the name: Al-Khader means "the green one" [[70]:288; [69]:9]. It is believed that every place on which Al-Khader sat became green. This concept may explain why so many trees are dedicated specifically to this prophet.

\section{Religious species ("holy trees")}

In many cultures (see Table 1) all the individual trees of certain species are sacred, the most famous being Ficus religiosa underneath which Buddha received his enlightenment [[71]:24; [32]:41-100]. The only tree in the Middle East that can be regarded as close to "holy tree" is Ziziphus spina christi, which is mentioned in the Quran. Individual trees of this species are highly respected, by Muslims, but are worshipped only in connection with a saintly person, and not per se. The Druzes treat this species at the same manner, but it is still regarded as a "blessed" tree [31]. All the other categories of worshipped trees (Table 1) can thus be considered as "sacred trees".

\section{Events under the tree}

In our survey Muslims as well as Druze mentioned events in the life of the saints/prophet/religious figures as one of the main reason for the sanctification of trees. Curtiss [[56]:93] noted that "trees under which saints rested are considered holy". We can add that it was sufficient for the saint to teach, preach, or pray under a tree to make it sacred. In Israel we failed to find even a single sacred tree that commemorates a specific historical event. In Britain, for example, many such cases are found, although it is hard to discern what comes first, the event or the sanctification of the tree [[26]:44,104], see also Table 1 for more eamples.I.

\section{Showing the way to a sacred place}

Near village of Mghar (Lower Galilee), on the main road to Nabi Shu'ayb (believed to be the grave of the prophet Jethro), the holiest place for Druze in Israel [[50]:217218], there is a huge Christ's Thorn Jujube (Z. spina christi) tree. In the past this important tree served as a meeting point for pilgrims before approaching the holy place for the festival of Nabi Sua'yb (on 25 April, every year). Whoever arrived first waited for the others under that tree. Over the years the tradition of the first meeting point took root, and this specific tree became a station for praying as well. It is the only individual tree of his kind that reached the status of a "blessed tree". When the pilgrims reached the tree they became very excited, and this is how the tree came to be named "Sidrat Nebi Shu'ayb" (the Prophet's Jujube) [31].

\section{Sprouting from a saint's staff}

In some places we heard that sacred trees had sprung from staffs carried by saints or religious pleaders. Similar stories are known also from other countries and are not endemic to our region (Table 1).

\section{Shadow in the desert}

This reason was mentioned only by the Bedouins and can be looked as vestiges of old traditions reflecting their history.

\section{Planting trees in sacred places/groves growing in sacred places and tree's as having healing powers}

These reasons are rare in the Middle East and are not common worldwide.

\section{Tree characters}

Only two of our interviewees mentioned tree size as a reason for its sanctification. In the literature (Table 1) large tree size and evergreen-ness are mentioned as important characters that lead to tree veneration. In Israel at least two of the common sacred trees are deciduous (Quercus ithaburensis and Pistacia atlantica). These two species can grow to a considerable size, and it seems that this is the very reason why they were venerated. These observations are run counter to Wilson [[62]:6] who maintains that all the oaks on saint's graves are evergreen. In one village (Sajur, Upper Galilee) there is a blessed Styrax officinalis tree; the keeper of the tree is convinced that this specific tree is Venerated (named al-Mubarakeh, meaning "the blessed") because it is said that it is the only evergreen individual of this deciduous species $(24$, it is a well known story in the village, $\mathrm{n}=12$ ). Our observation failed to corroborate this, although it is in a protected garden and the leaf fall is somewhat shorter in comparison with other Styrax trees growing in an exposed habitat. This case brings to mind a sacred platanus (Platanus orientalis) in Gortyna that was sanctified in Ancient Greece because it was an individual evergreen plant (the species is generally deciduous) and connected with the abduction of Europa [[3]: $7.1 ;[72]: 176]$.

Huge trees were objects of veneration and a manifestation of the Almighty [[23]:2; [73]:29]. The most famous "great tree" is the oak, which is the foremost tree in European mythologies and tree worship [75]; [76]:188-191; [77]:23]. In the words of Folkrad [[77]:21] "The Oak, the strongest of all trees, has been revered as the emblem of the Supreme Being by almost all the nations of heathendom" Porteous [[6]:150] explains why these trees were venerated: "As year after year passed with the same continual changefulness, trees, or perhaps one outstanding tree on account of its size and age, would come to be regarded with a special reverence, and primitive imagination would people it with all sorts of beings, such as Gods, Nymphs, 
and Demons". The Kikuyus in East Africa select large trees for veneration. A sacred tree must be high because it is deemed nearer to the god as a medium through which prayers are to ascend [[78]:4]. Sometimes the reason for sanctity is the strange or the unusual appearance of the tree rather it size [Japan [79:188; Inner Mongolia [[80]:279,283].

\section{Trees as an abode of super natural beings}

Trees that are the abode of deities, gods and ancestor' souls were never recognized in the Middle East, and it seems that these reasons are confined today to polytheistic religions. The recurrent pattern of this kind of sacred tree/forest/grove is highly typical: the tree/grove/forest is dedicated to a certain god/deity or ancestral soul, which is in charge of the welfare and well being of the community/ village. To ensure supernatural blessing, certain rituals must be performed to please the god or the ancestors to win their favour [[80]:1578; [18]:35; [81]:350-351].

\section{The tree is located near holy water source}

The survey of sacred trees in Israel ([77] and our observations) revealed that they are rarely adjacent/related to water sources; we were unable to find any evidence that this vicinity is the reason for the sanctification. In ancient Greece [[34]:20, 25, 34] sacred trees were sometimes associated with holy water sources. Concerning ancient Syria White states, "this early nature worship, whether of numerous Baalim of the Syrian oases or the local nymphs of the sacred springs of Hellas, required only the markedoff enclosure of holy ground beside the spring, or about the circle of trees in the sacred grove" [[82]:115]. Sacred trees associated with sacred wells are common in Britain even today [[35]:40-42; [83]:30].

\section{Conclusion}

Of the 24 known reasons for the creation of sacred trees/ groves/woods/forests 11 reasons (Table 1 , reasons 1 to 11) were recorded by us in the field while the other 13 were compiled from the literature and were almost never recorded from the Middle East. Only one reason (showing the way to a sacred place) was never recorded before and was found to be endemic to the Druze and is related to one specific very famous tree. Generally, most of the local reasons seem to be more confined to the monotheistic religions as "vestiges" of the old paganism (see below) and appear very rarely in polytheistic religions. Some of the remaining reasons (especially 13,16, and 18) are typical of polytheistic religions as a part of the regular rituals and are seldom mentioned in monotheistic areas. The evidence from ancient Europe, Egypt, and the Middle East may reflect the prehistoric pagan heritage that was partly adopted later by the monotheistic faiths. These replaced tree-dwelling spirits, gods, and souls by saint worship performed through the trees. Owing to the long and aggres- sive struggle of the monotheistic establishments (Jewish, Christian, as well as Muslim) with the old paganism, "tree adoration" became marginal and prevails today mainly in rural areas of the Middle East and North Africa.

In the pre-Islamic pagan world tree worship was quite common [[84]: 169-107; [14]:185; [85]:181]. These trees were worshipped as the abode of jinns and spirits, and were treated as possessing godly characters [[1]:30]. Several authors consider tree veneration in the Muslim world a relic of old heathen worship of tree-spirits or gods, which has survived, in a thinly disguised form, throughout all the ages of Christian and Islamic supremacy [[77]:242; [14]:199; [93]:50; [86]:34; [77]:92]. After the Arab conquest the tree spirits/deities/gods of the early heathen inhabitants were replaced, after the Arab conquest, by the spirits of the Muslim saints, the "Awlia" (= plural of Welli), which may survive and appear in sacred trees (Palestine [[77]:151]; Iran [[87], I:378]; Morocco [[88]:97]). A completely different view is expressed by Albright [[89]:284-286] who considers the Welli cult of Palestine and Syria as merely as a phase of the saint-cult of the Mediterranean region and differing only in detail from the saint-cult of the lower classes in other Mediterranean lands. Moreover, he argues that this saint-cult goes back to the Christian saint-cult of the Eastern Roman Empire in the early Byzantine centuries and is Hellenistic-Roman, not Semitic, in origin. Hornblower [[90]:19] similarly notes, concerning sacred trees in Egypt, that the local gods were replaced by local saints, first Christian and then Mus$\mathrm{lim}$. With the crystallization of Islam, these old venerated trees were cut down and this kind of worship was strictly forbidden [[91]:318; [92]:243-244]. The practical result, as can be seen today (Table 1), may be considered a kind of "functional religious replacement": no longer are the trees regarded as the abode of tree-spirits, deities, or gods, as in earlier heathen times, but as the abode of saints, who are regarded as the messengers of God himself. This kind of "softened idolatry" exists to the present day, despite the Islamic regime, which has proved too weak to eliminate it, especially in rural areas. In consequence of our survey, we fully agree with Frazer [[93]:43] who, very pithily, summarizes the status of sacred trees in the Middle East: "Thus the worship at the high places and green trees, which pious Hebrew kings forbade and prophets thundered against thousands of years ago, persists apparently in the same places to this day".

A review of the reasons for the creation of sacred trees/ groves (Table 1) shows some kind of dichotomy between the monotheistic legacy of the sacred trees in Europe, the Middle East and North Africa as against the polytheistic traditions in the world. In polytheistic religions, especially in Africa and Asia, people still see the sacred tree/grove as the abode of deities, ancestors' spirits, etc. (see Table 1), 
which may reflect the old "pagan" customs that prevailed in Europe, the Middle East, and North Africa at the remote past. Fergusson [[94]:62] noted that while all the monotheistic religions fought ancient tree worship, Buddhism elevated it to a higher level of veneration. According to Avasthi [[95]:7] polytheism in India allows multiplicity in worshipping objects like trees, rivers, or the village deity. These objects vary from person to person and festival to festival. The celebration is public whereas the worship of gods and goddesses takes place in the family.

In the polytheistic world the sacred grove/wood it is a centre of common tribal activities. Sometimes access is limited to certain people and/or certain occasions, and the grove is kept by the community or by a special priest, additionally to the general taboo not to harm the tree [Sierra Leone (36:311); Okinawa $(96: 5,18)$; East Timor ([97]:224); India ([41]:49; [98]:9; [99]:712); Russia ([100]:699); Zimbabwe ([101]:6); Northern Ghana ([18]:35); Vanatua (Pacific islands, [102]:9); Mozambique ([103]:229); West Africa ([104]:45)]. In the presentday Middle East the sacred tree is a centre for individual ritual behaviour with free access.

There is no doubt that the present-day vestigial tree worship in Europe is a result of "Christianization" of the old pagan religions. Elworthy [[105]:107-108] noted " The remarkable similarity in the customs (of tree veneration) all over Europe points to the conclusion that tree worship was once an important element in the early religion of mankind, especially of the Aryan stock, and that the singular uniformity of the rites and ceremonies which can easily be shown to exist in widely separated countries, fully warrants us in believing that they have not much changed from very remote ages, and that the practices continued down to a very recent period by peasantry.... were substantially identical with the same rites and ceremonies observed by Egyptians, Etruscans, Greeks and Romans". At this point it is fitting to cite Lucas [[35]:34] "At first, in brief, the church came to the [sacred] tree, not the tree to the church". Almost the same view is expressed by Robertson-Smith [[14]:186-187: "The worship of solitary trees survived the fall of the great gods of Semitic heathenism... The solitary tree may in certain cases be the last relic of a ruined heathen sanctuary". Likewise Porteous [[6]:162] comments that "It [tree worship] was... so deeply ingrained in the human hearts that in many cases it was utilized by the Church for its own ends by blessing the most ancient and venerated trees, and by erecting Christian altars and placing crucifixes and images the people had sacrificed to the heathen divinities" (see also [[8]:I,86-87]).

The present survey shows that tree veneration is still quite common in Israel among Muslims and Druze. The rea- sons for sanctification of trees are mainly connected with the adoration of saints and prophets. While the Muslims connected sacred trees with saints' souls and graves, the Druze, who believe in transmigration of souls, relate the blessed tree mainly to the events and activities of prophets and historical religious leaders.

A worldwide comparison shows the great similarity of the monotheistic religions, in which saint adoration is the main focus for tree worship. In polytheistic religions sacred trees are mainly connected with local gods, spirits, demons and ancestor veneration, none of which is found in the present-day Middle East.

\section{Declaration of competing interest}

The author(s) declares that he has no competing interests.

\section{Appendix}

List of the informants who are cited personally according to theirs appearance order in the text (Bold numbers in the text to differ from the literature sources) the given data are: The name of the informant, his age, ethnic group, place, and the date of the interview.

1. Zaki Abu Bilal Hashad, 67, Muslim imam, Tarshîha, 19 Dec. 2005

2. Qāsim Bader, 45, Druze, Keeper of the sacred place of Nabi Sabalān sanctuary, 9 June

2002.

3. Faraj Kiblawi, 67, Muslim, Tarsh\&\#x012B; †а, 19 Dec. 2005.

4. Hāmed abu Mustafa, 45, Muslin, 'Arrābe, 21. Dec. 2003.

5. Ruqqiya Maghis, 50, Joreih, Bedouin. 27 March 2005.

6. Qāsem Shibli, 32, Bedouin, Shibli 21. Oct. 2004.

7. Sa'\&\#x012B;d Muћmmad, 90, Druze, Yānuћ, 25 May 2003

8. Sa'\&\#x012B;d Maћamûd Sa'\&\#x012B;d, 69, Druze, YānuH, 25 May 2003.

9. Akab 'Amashe, 45, Druze Sheikh, Buq' ātha, 12 Dec. 2001.

10. Sheikh Nûr Rifa'\&\#x012B;yye, 40, Majdl Krûm, Sufi Muslim, 24. June 2000. 
11. Sheikh Šhah\&\#x012B;n Hussein, 70, Druze a religious leader, Beit Jan, 12. Sept. 2000.

12. 'Âdel Abu Hamid, 57, Muslim, Kufr Manda, 16 April 2004.

13. Hāmed abu Mustafa, 45, Muslim, 'Arrābe, 31. Dec. 2003.

14. Sa'di Qaramān, 75, Muslim, Damûn, 13 Sept. 2000.

15. Jam\&\#x012B;l Abu Rāiid Arafāt, 71, Muslim, Mashhad, 23. Sept. 2004.

16. Sāleh Hat\&\#x012B;b, 50, Mghar, Druze, 18 March 2003.

17. Karmel Na'ama, 52, Muslim, 'Arrābe, 6 June 2004.

18. Sueid Hussein,68, Druze, Peqee'in, 8 Nov. 2005.

19. Sheikh Tawkf\&\#x012B;q Amashe, 70, Druze, Mas'ade, 12 Dec. 2001.

20. Salmān Abu Rukan, 55, Druze, 'Isfia, 12 Dec. 2003.

21. Mustafa Halāwi, 48, Druze, 'Isfia, 15 Dec. 2003.

22. Maћmud Abu L'Raћman Mar'\&\#x012B;n, 67, Muslim, Meshhed, 20 Sep. 2004.

23. Yuval Avidor, 35, Jew, Yodfat. 21 Dec. 2003.

24. Zi'ad Tallāl, Druze, 35, Druze, Sajur, 3 Oct. 2003.

\section{Acknowledgements}

The author thanks Prof. Donald J. Hughes for his critical comments and inspiration, Say Levy and Morris Ttsemach for invaluable field assistance and Dr. Aharon Geva-Kleinberg for the Arabic transcription.

\section{References}

I. Frese PR, Gray SJM: Trees. In The Encyclopaedia of Religion Volume 15 Edited by: Eliade M. New York: Macmillan Library ReferenceUSA, Simon and Schuster and Macmillan; 1995:26-33.

2. Hughes JD, Chandran MDS: Sacred groves around the earth: an overview. In Conserving the Sacred for Biodiversity Edited by: Ramakrishnan PS, Saxena KG, Chanderashekara V. New Delhi: Oxford and JBH Publishing Co.; 1998:869-876.

3. Pliny. Natural History Transl. Rackham H London and Cambridge (Massachusetts): Harvard University Press; Loeb Classical Library; 1945.

4. Quantz JD: Dendro-psychosis. American Journal of Psychology I898:447-506.

5. MacCulloch JA: The Religion of the Ancient Celts Edinburg: T\&T Clark; I911.

6. Porteous A: Forest Folklore, Mythology and Romance London: George Allen and Unwin Ltd.; 1928.

7. Baumann H: Greek Wild Flowers and Plant Lore in Ancient Greece London: The Herbert Press; 1993.

8. Grimm J: Teutonic Mythology (Transl. Stalybrass JS:). New York: Dover Publications; Inc.; 1966.
9. Philpot JH: The Sacred Tree or the Tree in Religion and Myth. London: McMillan \& Co 1897.

10. Frazer JG: The Golden Bough: The Roots of Religion and Folklore. New York: Avenel Books 198I.

II. Chandran MD, Hughes JD: sacred groves of South India: ecology, traditional communities and religious change. Social Compass 1997, 44:413-427.

12. Hamilton LS: Forest tree conservation through metaphysical constraints. The George Wright Forum 2002, 19:57-78.

13. Binha BC: Tree Worship in Ancient India Delhi: Eastern Book Corporation; 1979.

14. Robertson-Smith W: Lectures on the Religion of the Semites. Edinburgh: Adam and Charles Black; 1889.

15. Mills J: Three Months' Residence at Nablus and an Account of the Modern Samaritans London: J Murray; 1864.

16. Eliade M: Patterns in Comparative Religion New York: Sheed and Ward; 1958.

17. Zahan D: The Religion, Spirituality and Thought of Traditional Africa Chicago and London: The University of Chicago Press; 1979.

18. Millar D, Aniah R, Atoyure P: Shrines and groves. COMPAS Newsletter 1999:34-36.

19. Loiskandl H: Time discipline in sacred places - origins and consequences. International Review of Sociology 200I, 3:357-369.

20. Gupta SS: Sacred trees across cultures and Nations Calcutta: Indian Publications; 1980.

2I. Eliade M: The Sacred and the Profane New York: Harcourt, Brance \& World Inc,; 1959.

22. Bechmann R: Trees and Man: The Forest in the Middle Ages (Transl. K. Dunham). New York:Paragon House; 1990.

23. Anonymous: Cultus Arborum - Phallic Tree Worship Privately Printed; 1890.

24. Pandey BP: Plants for Human Kind, Sacred Plants of India New Delhi Shree Poblishing House; 1989.

25. Gupta SS: Tree Symbols and Worship in India - a New Survey of a Pattern of Folk Re-ligion Calcutta: Indian Publications; 1965.

26. Morton A: Tree Heritage of Britain and Ireland Shrewsbury: Swan Hill Press; 1998.

27. Altman N: Sacred Trees San Francisco: Sierra Club Books; 2000.

28. Malla BL: Trees in Indian Art, Mythology and Folklore New Delhi: Aryan Books International; 2000.

29. Gupta SM: Plant Myth and Traditions in India 3rd edition. Calcutta: Munshiram Manoharlal; 200I.

30. Barns T: Trees and Plants. Encyclopaedia of Religion and Ethics 1910 , I 2:447-457

31. Dafni A, Levy S, Lev A: The ethnobotany of Christ's Thorn Jujube (Ziziphus spina-christi)in Israel. Journal of Ethnobiology and Ethnomedicine 2005, I: I 2-22.

32. Simoons FJ: Plants of Life, Plants of Death Madison: of Wisconsin Press; 1988.

33. Hughes JD: An Environmental History of the World London and New York:Routledge; 200I.

34. Birge DE: Sacred groves in the ancient Greek World. PhD. thesis, University of California Berkley, Department of Ancient History and Archaeology; 1982.

35. Lucas AT: The sacred trees of Ireland. Journal of the Cork Historical and Archaeological Society 1968, 68:16-54

36. Lebbie AR, Freudenberger MS: Sacred groves in Africa: forest patches in transition. In Fo-rest Patches in Tropical land Landscape Edited by: Schelhas J, Greenberg R. Washinton: Island Press; 1966.

37. Pandey R, Rao PV: Impact of globalization on culture of sacred groves: a revival of common, but decay of the traditional institution. In Ninth Biennial Conference of IASCP Zimbabwe; 2002:17-21. Paper submitted for

38. Campbell MO: Traditional forest protection and woodlots in the coastal savannah of Ghana. Environmental Conservation 2004, 3 I:225-232.

39. Ramakrishnan PS: Sustainable development, climate change and tropical rain forest. Climate Change 1998, 39:583-600.

40. Sreedharan TP: Biological diversity of Kerala, a survey of Kalliasseri Panchayat Knnur Dis-trict. Thiruvananthapurana: Kerala Research Programme on Local Level Development, Centre for Development Studies; Paper No.62; 2004

41. Gadgil M, Vartak VD: Sacred groves of Maharashtra: an inventory. In Glimpses in India Ethnobotany Edited by: Jain SK. New Delhi: Oxford University Press; 1981:279-294. 
42. Parthasarathy N, Karthikeyan R: Plant biodiversity and conservation of two tropical dry ev-ergreen forests on the Coromandel coast, south India. Biodiversity and Conservation 1997, 6:1063-1083.

43. Ramanujam MP, Kadamban D: Plant biodiversity of two tropical dry evergreen forests in the Pondicherry region of south Indian and the role of belief system in their conservation. Biodiversity and Conservation 200I, 10:1203-1217.

44. Khumongmayum AD, Khan ML, Tripathi RS: Sacred groves of Manipur, northern India: bio-diversity value, status and strategies for their conservation. Biodiversity and Conservation 2005, I 4: I54|-1582.

45. Freeman JR: Gods groves and the culture of nature in Kerala. Modern Asian Studies 1999, 33:257-302.

46. Sarton G: The artificial fertilization of date palms in the time of Ashur-Nasir-pal. B.C. 885-860. Isis 1934, 21:8-13.

47. Albenda P: Assyrian sacred trees in the Brooklyn museum. Iraq 1994, 36: I23-133.

48. Forlong JGR: Rivers of life London: Bernard Quaritch; 1883

49. Medzini A: Expansion of Bedouin settlement in Galilee resulting from spontaneous occupation and planned government policy. Monogeography No. I, Haifa: Department ofGeography; University of Haifa; 1984

50. Dana N: The Druze in the Middle East-their Faith, Leadership, Identity and Status Brighton and Portland: Sussex Academic Press; 2003.

51. Shmida A, Shamir T, Weinberger M: Sacred and veteran trees in Israel. Kim'at Alpayeem 1996, I 2:259-266. (In Hebrew)

52. Ilan Z: Tombs of the Righteous in the land of Israel Jerusalem: Cana; 1997.

53. Gilat Z: Graves of Tzadikim in Israel Tel Aviv Mapa Publishers; 2005.

54. Dafni $A$ : Why are rags tied to the sacred trees of the Holy Land? Economic Botany 2002, 56:3 I5-327.

55. Aumeeruddy $Y$ : Percieving and managing of natural resources in Kenrici, Summatra. Na-ture and Resources 1995, 31:28-37.

56. Curtiss SI: Primitive Semitic Religion to-Day London: Hodde and Stoughton; 1902.

57. Canaan T: Mohammedan Saints and Sanctuaries in Palestine. Jerusalem: Ariel. (Originally published 1927-1928, rep n.d.)

58. Patai R: Man and Earth Jerusalem: The Hebrew University; 1942.

59. Hasluck FW: Christianity and Islam under the Sultans Edited by: Hasluck MM. New York: Octagon Books; 1973.

60. Westermarck E: Ritual and Belief in Morocco New York: University Press Books; 1968.

61. Jaussen A: Coutumes des Arabes au pays de Moab Paris: Geuthner P; 1908.

62. Wilson C: Peasant Life in the Holy Land London: John Murray; 1906.

63. Thompson WM: The Land and the Book London Nelson; I88I.

64. Legey F: The Folklore of Morocco London George Allen and Unwin Ltd.; 1935.

65. Burton R, Tyrwhitt-Drake C: Unexplored Syria, Visits to the Libanus, the Tuel El Safi', the Antilibanus, the Northern Libanus and the Alah London: Tinsley Brothers; 1872.

66. Zarcone T: Stone people, tree people and animal people in Turkic Asia and Eastern Europe. Diogenes 2005, 207:35-46.

67. Blackman AM: Sacred trees in modern Egypt. Journal of Egyptian Archaeology 1925, 9:56-57.

68. Budge EAW: Osiris and Egyptian Resurrection New York: Dover Publications; 1973.

69. Augustinovic A: "El Khader" and the Prophet Elijah Jerusalem: Collectio Minor, Studium Biblicum Franciscarum: No. 12; 1972

70. Albright WF: Islam and the religions of the ancient orient. Journal of the American Oriental Society 1940, 60:283-30I.

7I. James ED: The Tree of Life Leiden: EJ Brill; 1966.

72. Chandran MDS, Hughes JD: Sacred groves and conservation: the comparative history of traditional reserves in the Mediterranean area and in south India. Environment and History 2000, 6:189-186

73. Cultus Arborum-Phallic Tree Worship. Privately Printed $\mathbf{1 8 9 0 .}$

74. Sinha BC: Tree Worship in Ancient India. New Delhi: Books Today; 1979:19-28.

75. Munro-Chadwick H: The oak and the thunder-god. The Journal on the Anthropological Insti-tute of Great Britain and Ireland 1900, 30:22-44.

76. Frazer JG: Aftermath, a Supplement to the Golden Bough London: Macmillan; 1963.

77. Parke HW: The Oracle of Zeus: Dodona, Olympia, Ammon Oxford: Basil Blackwell; 1967.
78. Folkrad R: Plant Lore Legends and Lyrics London: Sampson Bow, Barston \& Company; 1892.

79. Reader J: Japanese religions. In Sacred Space Edited by: Holm J. Pinter Publishers; 1994:187-202.

80. Ujiyediin C: Mongol tree worship. Archiv Orientální 1997:275-191.

8I. Khumbongmayum AD, Khan ML, Tripathi RS: Sacred Groves of Manipur, northeast India: biodiversity value, status and strategies for their conservation. Biodiversity and Conserva-tion 2005, I4:|154I-I582.

82. White KD: The sacred grove :a comparative study of some parallel aspects of religious ritual in ancient Crete and the Near East. Greece and Rome 1954, I: I I2- 27.

83. Giolláin DÓ: Revisiting the holy well. Volume 40. Ëirie-Ireland; 2005:II-4I.

84. Noble RR: The Tree symbol in Islam. Studies in Comparative Religions 1975, 20:164-182.

85. Nöldeke T: Geschichte der Preser und Araber zur Zeit der Sasaniden-Aus der Arabischen Chronik des Tabari, Übersetz ausfurlichen Ergänzungen Erläuterungen und Ergänzungen Leiden:Brill; 1973. (First published 1879)

86. Lees R: Village Life in Palestine London: Longmans, Green \& Co.; 1905.

87. Ouseley W: Travels in Various Countries of the East (I8/0-18/2.) London: Rodwel and Mar-tin; 1819.

88. Westermarck E: Pagan Survivals in Mohammedan Civilisation Amsterdam: Philo Press; 1933.

89. Albright WF: Islam and the religions of the ancient orient. Journal of the American Oriental Society 1940, 60:283-30I.

90. Hornblower GD: A sacred grove in Egypt. Man 1930, 30:17-19.

91. Goldziher I: Muslim Studies Edited by: Stern SM. London: George Allen and Unwin Ltd.; 1971.

92. Donaldson BA: The Wild Rue New York: Arno Press; 1973.

93. Frazer JG: 1919 Folklore in the Old Testament-Studies in Comparative Religion Legend and Law. New York and London: Macmillan; 1919.

94. Fergusson J: Tree and Serpent Worship London: WH Allen; 1868.

95. Avasthi A: Sacred beliefs and practices of Indian folk and environment. Paper presented at the 13th Congress of Sociology, Bielefeld: Germany Mimeo 1994. 18-23.7

96. Sered S: Woman of the sacred groves: divine priestesses of Okinawa Oxford: Oxford University Press; 1999.

97. Meitzner-Yoder LS: Customs, codification, collaboration: integrity of the legacies of land and forest authorities in Oecuse enclave, East Timor. PhD thesis, Yale University: Faculty of Graduate School; 2005.

98. Malhorta KC, Chatergee S, Gikhale Y, Srivastava S: Cultural and ecological dimensions of sacred groves in India New Delhi: Indian National Science Academy; 200I.

99. Deb D: Conservation ethos in local traditions: the west Bengal Heritage. Society and Natural Resources 200I, 14:7II-724.

100. Vovina PO: the road to the temple: religion and national reveal in the Chuvash republic. Nationalities Papers 2000, 28:695-706.

10I. Chidahakwa Z: Continuing the change: the role of dynamics of traditional institutions in the management of the Haroni and Rusitu forests in Chimanimani, Zimbabwe. CASS/PLAAS CBNRN 3rd Regional Workshop, Maputo, Mozambique; 200I. 89.10

102. Thaman RR: Batiri Kei Baravi: The Ethnobotany Pacific Island coastal plants. Atoll Research Bulletin 1992, 36: I-62

103. Virtanen $P:$ The role of customary institutions in the conservation of biodiversity: sacred forests in Mozambique. Environmental Values 2002, I I:227-24I.

104. McKenzie P: Hail Orisha; A Phenomenology of West African Religion in the Mmid-nineteen Century Leiden: Brill; 1997.

105. Elworthy TF: The Evil Eye New York: Julian Press; 1958.

106. Bar-Zvi S, Abu Rabi A, Kressel GM: The Charm of Graves: Mourning Rituals and Tomb Worshiping among the Negev Bedouin Tel Aviv: Ministry of Defence Press; 1958. (In Hebrew)

107. Drower ESS: Peacock Angel: being some account of the votaries of a secret cult and their sanctuaries London, J. Murray; 1941.

108. Hūsang A: Encyclopaedia Iranica Edited by: Costa-Mesa C. Mazdn Publishers; | $996: 316-319$

109. Ober FA: A look at Algeria and Tunis. Journal of the American Geographical Society of New York 1889, 21 :287-324.

I10. Zwemer SM: The Influence of Animism in Islam. London. McMillan; 1920. 
II I. Zaharony M, Weger E: Lametayel Bacarmel. Jerusalem: Szold Institute; 1967. (In Hebrew)

1 12. Bonavia E: The Flora of Assyrian Monuments London: Archibald Constable and Co.; 1894.

1 13. Reilly J: The peasantry of Late Ottoman Palestine. Journal of the Palestine Studies 198I, 10:82-97.

I 4. Atkins HJB: The French North African background: I. Islam. African Affairs 1947, 46:21-29.

I I5. Gombya-Sembajjewe WS: Sacred forests in modern Ganda society. The Uganda Journal 1995, 43:32-44.

116. Avasthe RK, Rai PC, Rai LK: Sacred groves as repositories of genetic diversity-a case study from kabi-Longchuck, north Sikkim. ENVIS Bulletin, Himalayan Ecology 2004, I 2:25-29.

1 17. Mutunga H: Waahi tapu; Maori sacred sites. In Sacred Sites Sacred Places Edited by: Carmichael E, Hubert J, Reeves B, Schanche A. New York and London: Routledge; 1994:217-226.

1 18. Rix NM: More Shropshire folklore. Folklore 1960, 7 I:|84-|87.

119. Hay-Edie T, Hadley M: Natural sacred sites - a comparative approach to their cultural and biological significance. In Conserving the Sacred for Biodiversity Edited by: Ramakris-hnan PS, Saxena KG, Chanderashekara V. New Delhi:Oxford and JBH Publishing Co.; 1998:45-77.

120. Falconer J: Non-timber forest products in southern Ghana: traditional and cultural forest values. In Cultural and Spiritual values of Biodiversity Edited by: Posey A. London: Interm-ediate Technological publications, UNEP; | 99|:366-37.

I2I. Chouin G: Sacred groves in history pathways to the social shaping of forest landscape in coastal Ghana. IDS Bulletin 2002, 33:39-46.

122. Stevens S: Tourism and deforestation in Mt. Everest region of Nepal. The Geographic Journal 2003, 169:255-277.

123. 'Arráf S: The Status of the Prophets and Saints in the Holy Land Tarsikha: Ikhwan Mahul; 1993. (In Arabic)

124. Vilnay Z: Legends of Eretz Israel 7th edition. Jerusalem: Kiryat Sefer; 1970.

125. Boyce M: Bibi Shahrbanum and lady Par. In Bulletin of the School of Oriental and African Studies Volume 30. University of London; 1967:29-44.

126. Wilson HH: Vishnu Purana, Punthi Pustak, Cacutta cited by Chaudhuri HN, Pal DC: Plants in folk religion and mythology. In Contributionto Indian Ethnobotany 3rd edition. Edited by: Jain SK. Jodhpur: Scientific Publications; 1997: 17-24.

127. Basset R: Revue des Traditions Populaire XXII, 1907 cited by Eliade M: The Sacred and the Profane. New York: Harcourt, Brance \& World Inc.; 1959.

128. Cowan J: The Maori of New Zealand Christchurch: Whithcombe and Tombs; 1910.

129. Maspero G: Dawn of Civilization, Egypt and Chaldaea London: Society for Promoting Chri-stian Knowlegde; 1894.

130. Chandervaker P: Tree cult in Saurashtra. In Tree Symbols in India, a new survey of pattern of folk religion Volume 5. Edited by: Gupta SS. Calcutta: IndianPublications; Indian Folklore Series; 1965:41-46.

131. Madeweya KH, Hoka H, Matsumoto M: Sustainable management of sacred forests and their potential for eco-tourism in Zanzibar. Bulletin of FFPRI 2004, 3:33-48.

132. Dowden K: European Paganism : The Realities of Cult from Antiquity to the Middle Ages London: Routlrdge; 2000.

133. Lubbock E: Early Races of Scotland and their Monuments Edinburgh: Edmonton and Douglas; 1870

134. Chien Y: Three Types of Chinese Deities, Stone Tree and Land PhD thesis, Lancaster University; 1997.

135. Taylor JG: Journal of a tour in Armania, Kurdistan and upper Mesopotamia with notes on researches in the Deyrsim Dagh in 1866. Journal of the Royal Geographical Society of London 1868, 38:28I-36I.

136. Harris WT: The Springs of Mende: Belief and Conduct Freetown: Sierra Leone University Press; 1968

137. Crooke W: The tribes of the central India hills. Journal of the Anthropological Institute of Great Britain and Ireland 1899, 28:220-248.

138. Long C-L, Zhou Y: Indigenous community forest management of Jinuo people's swidden agro ecosystems in southwest China. Biodiversity and Conservation 200I, 10:753-767.

139. Okello-Abungo GH: Islam on the Kenyan coast: an overview of Kenyan coastal sacred sites. In Sacred Sites Sacred Places Edited by: Carmichael DL, Hubert J, Reeves B, Schanche A. London and New York: Routledge; 1994:152-162.
140. Mumah MM: Sacred sites in the Bamenda grassfield of Cameroon: a study of sacred site in the Nso' Fondom. In Sacred Sites Sacred Places Edited by: Carmichael E, Hubert J, Reeves B, Schanche A. New York and London: Routledge; 1994:99-I I 4.

14I. Ovsyannikov OV, Terebikhin NM: Sacred spaces in the culture of the Arctic Regions. In Sacred Sites Sacred Places Edited by: Carmichael E, Hubert J, Reeves B, Schanche A. New York and London: Routledge; 1994:44-8I.

142. Gamble S: Ting Hsien:A North China Rural Community. Stanford: Stanford University Press; 1954.

143. Johnston H: The Uganda Protectorate. London: Huchinson; 1902.

144. Khaneghah AA: Social and cultural aspects of sacred trees in Iran. In Conserving the Sacred for Biodiversity Edited by: Ramakrishnaan PS, Saxena KG, Chanderashekara V. New Delhi: Oxford and JBH Publishing Co.; 1998:123-127.

145. Knight $\mathrm{J}$ : Tatari livelihood and danger in upland Japan. In Local Knowledge of Forest and Forest Uses among Tribal Communities in India Edited by: Seeland K, Schmithusen F. Zu-rich: Depaertment of Wald und Holzforchung; 1997: 127-148.

146. Neef A: Access to natural resources in Mainland Southeast Asia and implications for sus-taining rural livelihoods - the case of Thailand. Quarterly Journal of International Agri-culture 1993, 42:329-350.

147. Veer C: Best practices and knowledge sharing in watershed management in the lower Mekong basin. Bangkok: Working Paper 14, ARC-GTZ Corporation Programme. Agricul-ture, Irrigation and Forestry Programme, Watershed Management Project (WSMP) 2004:66-82.

148. Wadley RL, Pierce PD, Colfer CJ: Sacred forests, hunting and conservation in West Kali-mantan, Indonesia. Human Ecology 2004, 32:313-338.

149. Withanage H: Role of sacred groves in conservationand management of biodiversity in Sri Lanka. Conserving the Sacred for Biodiversity Management 1998:169-186.

150. Stevens S: Tourism and deforestation in Mt. Everest region of Nepal. The Geographical Journal 2003, 169:255-277.

15I. Buhl ML: The Goddesses of Egyptian tree cult. Journal of Near Eastern Studies 1947, 6:80-97.

152. Evans A: Mycenaen tree and pillar cult and its Mediterranean relations. The Journal of Hellenistic Studies 1901, 21:99-204.

153. Godlobe $\mathrm{E}$ : Role of tribal in preservation of sacred forests. In Ethnobiology in Human Welfare Edited by: Jain SK. New Delhi: Deep Publication; 1996:345-348.

154. Binggeli P: Workshop discussion. In Report of the Workshop on the Biodiversity Conservation in Ancient Church and Monastery Yards in Ethiopia. Adiss Abeba. 200 I Edited by: cited by Soutter R, Ntiamoa-BaiduY, Smith J, Rana D. Recognizing the contribution of sacred natural sites for biodiversity conservation. Lecture Presented at the World Park Congress, Durham, South Africa; 2003:34-56.

155. Curtin J: Journey in Southern Siberia: The Symbol of their Religion and their Myth Kessinger Publishing; (Google: Print); 2004.

156. MacCormick C: Proto-social to adult: a Sherbro transformation. In Nature, Culture and Gender Edited by: MacCormaik CP, Strathern M. Cambridge: Cambridge University Press; 1980:95-I I8.

157. Anoliefo GO, Isikhuemhen OS, Ochije NR: Environmental implications of the erosion of cultural taboo and practices inAwka-south local government area of Anambra state, $\mathrm{Ni}$ geria I. Forests, trees and water resource preservation. Journal of Agricultural and Environ-mental Ethics 2003, 16:28I-296.

158. Séne EH: Trees, forests, belief and religion in Sahelian Africa. Unasylva 2002, 54:44.

159. Roscoe J: The Baganda. An Account of their Native Customs and Beliefs London: Macmillan; 1911.

160. Davis W: Shadows in the Sun: Essays on the Spirit of Place Edmonton: Lone Pine Publishing; 1992.

161. Huabin H: Sacred natural sites in Xishuangbanna in southwestern China. In The Importance of Sacred Natural for Biodiversity Conservation. International Workshop on the Importance of Sacred Natural Sites for Biodiversity Conservation Edited by: Lee C, Schaaf T. Kunming andXishuangbanna Biosphere Reserve, China UNESCO, MAB, CAS, IUCN. 17-20.2.; 2003:127-I33.

162. Lyons AP: Tree reverence amongst Papuans. Man 1923, 23:72-73

163. Henry A: The Lolos and other tribes of Western China. Journal of the Anthropological Institute of Great Britain and Ireland 1903, 33:96-107. 
164. Hermann TM: Knowledge, values, uses and management of Aracauria araucana by the indigenous Mapuche people: a basis for collaborative naturalresource management in Chile. Natural Resources Forum 2005, 29:120-134.

165. Majupuria TC, Johshi DP: Religious and Useful Plants of Nepal and India Lashkar: Gupta M; 1997.

166. Khanjyan N: Specially Protected Nature Areas of Armenia. Yerevan: Ministry of Nature Protection of the Republic of Armenia; 2004.

167. Metzgar E: Sacred space, taboo place, negotiating Roang on Lamotrek Atoll, Micronesia. Journal of the Humanities and Social Sciences 2004, 3:2-18.

168. Mlehe G, Mlehe S, Koch K, Will M: Sacred forests in Tibet. Mountain Research and Development 2003, 23:342-328.

169. Aagensen DL: Indigenous resources rights and conservation of the monkey-puzzle tree (Araucaria araucana). A case study from southern Chile. Economic Botany 1998, 52:146-160.

170. Parrinder G: West Africa religion. London: Epworth Press; 1949.

171. Wellby MS: Through Tibet to China. The Geographical Journal I898, I 2:262-278.

172. Fleming PA: Journey through Central Asia. The Geographical Journal 1936, 88:128-144.

173. Bhasin V: Religions and cultural perspectives of sacred sitesSitabari in Rajasthan. Journal of Human Ecology 1999, 10:329-340.

174. Foppes J, Ketphane S: Forest extraction or cultivation? Local solution from Lao PDR. In Workshop on the Evolution an Sustainability of "intermediate Systems" of Forest Manage-ment, FOREEASIA Lofoten, Norway; 2000. 28.6-1.7

175. Fowler CT: The ecological implications of ancestral religion and reciprocal exchange in a sacred forest in Karendi (Sumba, Indonesia). World Views 2003, 7:303-329.

176. Horning NR: Explaining compliance with rules covering common-pool forest resource use and conservation: dynamics in Bara country, southwestern Madagascar. In Meeting of the International Association for the Study of Common Property Bloomington, Indiana; 2000. 31.5-4.6

177. Pearson MP: Madagascar. Nyame Akuna 1996, 45:60-64.

178. Posselt $F$ : The tree in the religious rituals of the Bantu of Southern Rhodesia. Man 1939, 39:126-127.

179. Schaaf T: Report on the Workshop on Natural Sacred Sites. Cultural Diversity and Bio logical Diversity. Paris: UNESCO;Symposium, CNRS, MNHN, National Museum of Natural History 1998: I43-152.

180. Mutoro HW: The Mijikenda as a sacred site. In Sacred Sites Sacred Places Edited by: Car-michael E, Hubert J, Reeves B, Schanche A. New York and London: Routledge; 1994:135-139.

18I. Firehead J, Leach M: Misreading the African Landscape; Society and Ecology in a Forest Savanna Mosaic. African Studies Series 90. Cambridge: Cambridge University Press; 1996.

182. Fujita $Y$ : Augmentity missing linkages: conservation and continuity resource management in Lao PGR. In Proceedings of the IASCP IOth Biennial Conference Oxana: Mexico; 2004:9-13. Au-gust 2004

183. Muddurooroo A: Aboriginal Mythology London: Thorsons; 1994.

184. Dukinfield-Astley $\mathrm{HJ}$ : A sacred spring and tree at Hamman R'Ihra, Algeria. Man 1910, 10:22-123.

185. Dallas D: The sacred tree of Oi Donyesha. Man 1931, 3 I:39-4 I.

186. Omura H: Trees and religion in Japan. Mountain Research 2004, 24: $180-183$.

187. Aston WG: The Japanese Gohei and Ainu Inao. Journal of the Anthropological Institute of Great Britain and Ireland I90I, 3 I: I3I-I 35.

188. Chandrakanth MG, Bhat MG, Accavva MS: Socioeconomic changes and sacred groves in south India: protecting a community-based resource management institution. Natural Resources Forum 2004, 28: 102-11.

189. Hobley CW: Further researches into Kikuyu religions beliefs and customs. The Journal of the Royal Anthropological Institute of Great Britain and Ireland 191 I, 4I:406-457.

190. Sumner WG: The Yakuts. Journal of the Anthropological Institute of Great Britain and Ire-land 1901, 31:65-110.

191. Redimilahy C: Sacred sites in Madagascar. In Sacred Sites Sacred Places Edited by: Carmi-chael E, Hubert J: Reeves B, Schanche A. New York and London: Routledge; 1994:82-88.

192. Malhorta KC: Anthropological dimensions of sacred groves in India - an overview. In Con-serving the Sacred for Biodiversity Edited by: Ramakrishnaan PS, Saxena KG, Chanderashekara V. Delhi: Oxford and JBH Publishing Co.; 1998:423-438.
193. Godlobe A, Watv A, Prabhu S, Sarnaik J: Role of sacred groves in biodiversity conservation with local people's participation: a case study from Rathnagiri District, Maharastra. In Conserving the Sacred for Biodiversity Edited by: Ramakrishan PS, Saxena KG, Chanderashekara V. New Delhi: Oxford and JBH Publishing Co.; 1998:233-252

194. Graham DC: The Lolo of Szechuan Province, China. American Anthropologist 1930, 32:703-705.

195. Levy S: Faith and worship of the Bedouins in Sinai. Tel Aviv: The Society fro Protection of Nature 1980. (In Hebrew)

196. Seneca: Epistualae Morales:Letters I-LXV. Vol.I. (Transl. Gummere RM:) Cambridge: Loeb Classical Library; 1917.

197. Choudhury AR: Hinduism. In Sacred Sites, Sacred Places Edited by: Carmichael L, Hubert J, Reeves B, Schanche A. London: Pinter Publishers; 1994:62-87.

198. Ozols J: Zur Frage der heiligen Wälder im östlichen Ostseegeleibt. Zeitschrift für Ostforschung 26:67I-68I.

199. Palmer M, Palmer N: Sacred Britain - a Gguide to the Sacred Sites and Pilgrim rroutes of England, Scotland and Wales London: Piatkus; 1997.

200. Einbender L, Wood DB: Social forestry in the Navajo nation. Journal of Forestry 1991, 89:12-18.

20I. Plutarch: Moralia Vol. 5 Isis and Osiris (Transl. F.C. Rabbit) Cambridge: Harvard University Press; 1936.

202. Amirthalingam M: Folklore of sacred groves. Indian Folklore 2000, 1:9-19.

203. Chilundo AC, Cau BM: Traditional forms of common property rights: a case study in Mozambique. Digital Library of the Commons [http://dlc.dlib.indiana.edu/archive/00000235/]. Indiana University

Publish with Biomed Central and every scientist can read your work free of charge

"BioMed Central will be the most significant development for disseminating the results of biomedical research in our lifetime. "

Sir Paul Nurse, Cancer Research UK

Your research papers will be:

- available free of charge to the entire biomedical community

- peer reviewed and published immediately upon acceptance

- cited in PubMed and archived on PubMed Central

- yours - you keep the copyright
BioMedcentral 